\title{
НАРУШЕНИЕ ЗАПРЕТОВ И ОГРАНИЧЕНИЙ ПРИ ПЕРЕМЕЩЕНИИ ТОВАРОВ ЧЕРЕЗ ТАМОЖЕННУЮ ГРАНИЦУ ЕАЭС И (ИЛИ) ГОСУДАРСТВЕННУЮ ГРАНИЦУ РОССИЙСКОЙ ФЕДЕРАЦИИ: ОТДЕЛЬНЫЕ ПРОБЛЕМЫ ТОЛКОВАНИЯ И ПРИМЕНЕНИЯ СТ. 16. 3 КОАП РФ
}

\author{
(c) 2020 Матвиенко Галина Владимировна \\ кандидат юридических наук, доцент \\ профессор кафедры правового обеспечения экономической деятельности \\ Российский государственный университет правосудия, Россия, Москва \\ E-mail: galina7772005@yandex.ru
}

Ввиду образования Таможенного союза ЕврАзЭС, а затем и Евразийского экономического союза, значительные изменения претерпела система запретов и ограничений торговли товарами, устанавливаемых на уровнях интеграционного образования и национальном. При этом административная ответственность за несоблюдение торговых барьеров предусмотрена в КоАП РФ. Надлежит выяснить, какие вопросы в практике порождает такой сложный, «многослойный» правовой режим перемещения товаров через таможенную границу ЕАЭС на примере применения ст. 16.3 Кодекса.

В целях унификации практики установления барьеров в торговле странам Союза предлагается ориентироваться на нормы интеграционного образования, привести в соответствии с ними положения законодательства об административной ответственности за нарушения запретов и ограничений. На основе анализа российской судебной практики приводятся доводы в пользу принятия постановления Пленума Верховного Суда РФ по актуальным проблемам применения КоАП. Вносится ряд предложений отечественному законодателю (в свете предстоящих реформ норм об административной ответственности) и Евразийской экономической комиссии.

Ключевые слова: запреты и ограничения в торговле, Евразийский экономический союз, таможенная граница, нарушение таможенных правил, административные наказания за нарушения таможенных правил.

Практика применения статьи 16.3 КоАП РФ [6] обширна. Она считается одной из самых «работающих» ввиду роста числа барьеров во внешней торговле товарами.

Так в 1 квартале 2020 года таможенными органами возбуждено 35929 дел об административных правонарушениях, из них по ст. 16.3 4321 дело (12\%) [12].

Верховный Суд РФ разъяснял отдельные вопросы, связанные с толкованием положений названной статьи в 2006 году [19]. Поскольку за этот период значительно поменялось законодательство и торгово-политическая обстановка, содержание ее положений претерпело существенные изменения, однако проблемы в толковании и применении возникают в современный период и требуют решения.

Система запретов и ограничений является неотъемлемой частью правового режима перемещения товаров через таможенную границу интеграционного образования, что логически вытекает из положений пункта 1 ст. 7 Таможен- ного кодекса ЕАЭС [2]. Законодатель уточняет: выпуск товаров для личного пользования в свободное обращение или для вывоза также невозможен без соблюдения запретов и ограничений [2, пп. 2 п. 2 ст. 262]. К ним относятся меры: нетарифного регулирования; технического регулирования; санитарные, ветеринарно-санитарные, карантинные, фитосанитарные меры; меры экспортного контроля, в том числе меры установленные в отношении продукции военного назначения; радиационные требования [см. 2, пп. 10 п. 1 ст. 2].

В Таможенном кодексе ЕАЭС, как и в Договоре о Союзе [1], среди барьеров в торговле названы также меры защиты внутреннего рынка (антидемпинговые, специальные защитные и компенсационные), устанавливаемые в отношении отдельных категорий ввозимых товаров по итогам специального расследования, которые, впрочем, в отечественном законодательстве причислены к мерам нетарифного регулирования [42]. 
Если перемещение товаров связано с осуществлением участником ВЭД предпринимательской деятельности (и товар, как правило, помещается под определенную таможенную процедуру), в каждом конкретном случае такого перемещения декларант самостоятельно выясняет, какие запреты и ограничения надлежит соблюдать при выборе того или иного режима пребывания товара на территории Союза или за его пределами, собирает необходимый пакет разрешительных документов.

Для удобства участников ВЭД Комиссия Союза ведет сводный перечень товаров, в отношении которых применяются нетарифные барьеры в торговле [31], а также устанавливает единые списки товаров, подлежащих:

- обязательной сертификации в соответствии с союзными техническими регламентами [32] (так, при ввозе таких товаров к декларации на товар прилагается сертификат соответствия либо декларация о соответствии);

- санитарно-эпидемиологическому надзору (контролю) (при ввозе товара требуется получить свидетельство о государственной регистрации по установленной единой в Союзе форме);

- ветеринарному контролю (надзору) (при ввозе товаров следует предъявить ветеринарный сертификат установленного в ЕАЭС образца);

- фитосанитарному контролю (при ввозе товаров предъявляется фитосанитарный сертификат международного образца) [1; 27].

Для физических лиц, перемещающих товары для личного пользования, обозначенное выше в статье 7 ТК ЕАЭС требование сохраняется, однако в таком случае проще определить, надлежит ли соблюдать то или иное ограничение, либо ввоз допускается без соответствующих разрешительных документов. В мировой практике действует общий стандарт: физические лица максимально освобождены от бумажной волокиты и вправе рассчитывать на послабления в соблюдении установленных ограничений. Это объясняется спецификой назначения товара, незначительным его количеством. За Евразийской экономической комиссией закреплена обязанность формировать «сводный перечень товаров для личного пользования, в отношении которых при перемещении через таможенную границу Союза подлежат соблюдению запреты и ограничения» [2, п. 9 ст. 256 ТК ЕАЭС]. Действительно, такие перечни Комиссия исправно ведет и публи- кует на своем официальном сайте [14]. По сути, для этой категории товаров формируется негативный список: что прямо не запрещено или не ограничено к перемещению, разрешено. Заметим также, что отдельные товары поименованы как не относящиеся к товарам для личного пользования (например, солярии для загара, икра осетровых рыб весом свыше 250 грамм и многие другие) [13]. Важная оговорка: Комиссия ведет перечни товаров для личного пользования, в отношении которых надлежит соблюдать запреты и ограничения, установленные на уровне Евразийского экономического союза. Что касается национальных барьеров в торговле [42] - они в сводном перечне Союза не отражаются.

Таким образом, итоговый список запретов и ограничений, которые надлежит соблюдать декларанту любой категории при перемещении товара через таможенную границу ЕАЭС, зависит от требований, установленных на уровне интеграционного образования и правил страны Союза прибытия (убытия), в которой будет осуществляться выпуск товара (т.е. завершено его таможенное оформление). Сложно? Несомненно. Но объяснимо с точки зрения защиты интересов интеграционного образования, а также наличия у каждого государства Союза права устанавливать ограничения в торговле с третьими странами с учетом национальных интересов $u$ обеспечения безопасности, в том числе меры, отличные от установленных на уровне Союза. Так, например, раздел X Протокола о мерах нетарифного регулирования в отношении третьих стран (Приложение № 7 к Договору о ЕАЭС) позволяет устанавливать государства - членам ЕАЭС временные меры по отношению к третьим странам в одностороннем порядке, в том числе по основаниям, не обозначенным в союзном Протоколе. Аналогичная норма содержится в ст. 32 Закона об основах государственного регулирования внешнеторговой деятельности. К таким мерам причислены необходимые для соблюдения морали и общественного правопорядка, обороны страны и безопасности государства, сохранение культурного наследия и иные. Это еще одна группа барьеров в торговле. К их числу, помимо поименованных выше, следует относить специальные экономические меры [39] и меры воздействия (противодействия) [41].

Договор о ЕАЭС и национальное законодательство сохраняет за государствами-членами Союза право применять в одностороннем по- 
рядке меры особого характера. В России к ним отнесены барьеры направленные на обеспечение соблюдения международных санкций (например, эмбарго), поддержание равновесия платежного баланса, обеспечение стабильности национальной валюты (например, валютные ограничения), ответные меры (предполагающие т.н. симметричный ответ на недружественные действия) [42, глава 8].

Проблема разработки единой классификации запретов и ограничений в торговле на мировом уровне, в рамках интеграционных образований и в национальных законах неоднократно поднималась международными экспертами и в научных исследованиях по экономике [30, С. 2570] и юриспруденции [например, 35, С. 216-227; 36, С. 10-50]. Отсутствие единого подхода порождает путаницу в толковании положений союзных и национальных нормативных актов лицами, обязанными соблюдать установленные правила: нередко декларанту довольно сложно выяснить, какой именно разрешительный документ требуется получить.

Современная редакция статьи 16.3 КоАП содержит единственный состав нарушения таможенных правил, т.е. административные наказания установлены за несоблюдение любых запретов и ограничений, без дифференциации их на виды. Заметим, что аналогичный подход применяется и в других странах ЕАЭС [5; ст. 545]. Законодатель учитывает также, что меры могут быть введены в одностороннем порядке и даже применяться при перемещении товаров во взаимной торговле между государствами-членами ЕАЭС. Именно поэтому названная статья устанавливает административную ответственность за нарушение запретов и ограничений при ввозе на таможенную территорию ЕАЭС и (или) в Российскую Федерацию и при вывозе товаров с таможенной территории Союза или из России.

Заметим, что в Проекте новой редакции КоАП РФ в числе запретов и ограничений особо обозначены меры защиты внутреннего рынка. Статья, идентичная ст. 16.3 действующего Кодекса, также не содержит отдельных составов в зависимости от видов запретов и ограничений, и называется «Несоблюдение запретов и (или) ограничений, а равно мер защиты внутреннего рынка» [25, ст. 32.3]. Таким образом прослеживается тенденция выделения и в национальном законодательстве из нетарифных барьеров специальных защитных, антидемпинговых и компенсационных мер. Такой подход вполне отвечает союзным нормам.

Ввиду бланкетного характера положений статьи 16.3 КоАП РФ, а также обширной и сложной материально-правовой составляющей режима перемещения отдельных категорий товаров, в отношении которых такие запреты и ограничения установлены, в практике возникают вопросы.

Приведем ряд примеров.

В 2014 году в целях защиты национальных интересов указом Президента РФ, согласно законам о специальных экономических мерах и о безопасности, был установлен запрет на ввоз ряда сельскохозяйственных товаров на таможенную территорию Российской Федерации из европейских государств, руководство которых установило экономические санкции в отношении отечественных компаний и физических лиц, либо присоединилось к такому решению. В первоначальной редакции рассматриваемого акта не было четко прописано, что действие его норм не распространяется на таможенную процедуру транзита. Отсутствие пояснения в тексте указа создало почву для нарушений международного стандарта регулирования внешней торговли - свободы международного транзита. Неверное толкование документа позволяло распространять его действие на внешнеторговые сделки, «место совершения и исполнение которых находились за пределами Российской Федерации», на что и указал совершенно справедливо Верховный Суд РФ в одном из определений [8] по итогам рассмотрения кассационной жалобы по делу об административном правонарушении, квалифицированному по статье 16.3 КоАП РФ по факту транзита через Россию картофеля из Финляндии в Грузию. Аналогичные позиции встречаются и в более поздних судебных решениях [например, 9; 15]. Заметим, что в практике судов общей юрисдикции встречается и противоположное мнение: суд полагает, что перевозчик транзитного санкционного груза обязан выбирать иные пути доставки товара, учитывая запрет на ввоз такой продукции в Россию [18].

Думается, этот вопрос требует однозначного разъяснения на уровне Пленума Верховного Суда РФ, что позволит обеспечить «определенность и стабильность результатов правореализационных процессов» [3, С. 368]. Планируемые реформы в законодательстве об административной ответственности проблемы не решат, 
поскольку все это по большей части - вопросы правоприменения.

Заметим, что в современной редакции рассматриваемого указа Президента РФ, транзит обозначенных товаров разрешен автомобильным и железнодорожным транспортом при условии обеспечения их прослеживаемости с использованием системы контроля, предусматривающей применение средств идентификации (пломб), функционирующих на основе технологий навигационной спутниковой системы ГЛОНАСС [38]. Это нововведение вполне отвечает риск-ориентированному подходу, применяемому в ходе отправления таможенных формальностей, и глобальной задаче обеспечения повышения безопасности международной цепи поставок [29].

Рекомендательный характер отдельных положений международных актов также может порождать споры в толковании положений ст. 16.3 КоАП РФ.

Так, например, согласно статье 5 Международной конвенции по карантину и защите растений [7], каждая сторона принимает меры по фитосанитарной сертификации подкарантинных растений, а разрешительный документ оформляется по установленному международному образцу, заполняется в соответствии с мировыми стандартами. В практике возникают споры: должен ли фитосанитарный сертификат содержать информацию о номере вагона, если товар перемещается железнодорожным транспортом? Следует отметить, что руководство по фитосанитарным сертификатам Международного стандарта по фитосанитарным мерам (МСФМ № 12) предписывает отражать в документе достаточно подробную информацию о товаре, позволяющую его идентифицировать, проверить количество. Что касается номера контейнеров и/ или вагонов - эта информация рассматривается как полезное дополнение к описанию упаковки и может быть включена, если известна. То есть отсутствие этой информации в фитосанитарном сертификате либо указание в нем номера вагона, отличного от прибывшего (или убывающего), состава нарушения таможенных правил, квалифицируемого по ст. 16. 3 КоАП РФ, не образует. Такое разъяснение встречается в мотивировочной части постановлений судов общей юрисдикции, причем принимаемых как в отношении нарушителя - экспортера, так и импортера [22; 23]. Совершенно справедливо в этом случае не- доумение сотрудников таможенных органов: как узнать, к какому товару относится сертификат? Ответ очевиден: осуществить сплошной таможенный досмотр. Учитывая объемы поставок не сложно представить, какими издержками это грозит декларанту и казне.

В настоящее время фитосанитарный сертификат на вывозимый товар может быть признан недействительным при отсутствии информации о номере транспортного средства, «если требование об обязательном указании в фитосанитарном сертификате номера транспортного средства предусмотрено законодательством страны-импортера, карантинным фитосанитарным требованиям которой должна соответствовать продукция». О вагонах и контейнерах в Правилах ничего не сказано [20].

В условиях функционирования Евразийского экономического союза этот вопрос надлежит решать на уровне интеграционного образования, внести дополнение в союзное Положение о порядке осуществления карантинного фитосанитарного контроля [33] и закрепить обязанность указывать в фитосанитарном сертификате номер вагона и/или контейнера, в котором подконтрольный товар следует через таможенную границу ЕАЭС, изменить соответствующий отечественный нормативный акт [24]. В первую очередь это требование необходимо предусмотреть для сертификатов, выдаваемых в отношении вывозимой продукции, поскольку до оформления убытия товара несложно узнать, в какой вагон (контейнер) он загружен.

В практике нередко встречаются случаи незаконного перемещения физическими лицами товаров группы риска. Типичный пример - ввоз табачной продукции сверх установленных ограничений. Согласно приложению № 1 к решению Совета ЕЭК № 107 допускается вво3 «200 сигарет, или 50 сигар (сигарилл), или 250 г табака, или указанные изделия в ассортименте общим весом не более 250 г в расчете на одно физическое лицо, достигшее 18-летнего возраста» при условии соблюдения установленных стоимостных ограничений беспошлинного ввоза. Ввоз указанной категории товаров сверх лимита физическими лицами для личного пользования запрещается. Если товар ввезен в Россию в целях осуществления предпринимательской деятельности, такая продукция подлежит обязательной маркировке акцизными марками. В противном случае товар признается находящимся в незаконном обороте. 
В данной ситуации не имеет значение - ввезен табак из государства-члена ЕАЭС или из третьих стран. Правовой режим перемещения табака и изделий из него установлен:

- на международном глобальном уровне Рамочной конвенцией ВОЗ против табака [28], в которой предусмотрено требование маркировки каждой его пачки и упаковки;

- на уровне интеграционного образования - в союзном техническом регламенте, согласно которому такие изделия маркируются единым знаком обращения продукции на рыке ЕАЭС [34];

- на уровне национальном - законами и подзаконными нормативными правовыми актами. Так, отдельный Закон содержит требование маркировки названных изделий средствами идентификации, а также маркировки в соответствии с правилами технического регулирования [43, ч. 3 ст. 18]; отечественное таможенное законодательство закрепляет право Правительства РФ устанавливать запреты на ввоз отдельных товаров по правилам, отличным от предусмотренных на уровне ЕАЭС, и наделяет таможенные органы контрольными полномочиями за соблюдением требования маркировки рассматриваемых изделий [40, пункт 3 части 1 ст. 212]. В отдельном постановлении Правительства РФ содержится запрет на ввоз рассматриваемой продукции без акцизных марок [21].

«Вечно зелеными» в правоприменении являются вопросы назначения административных наказаний за нарушения таможенных правил. Статья 16.3 КоАП РФ здесь не является исключением. Вернемся к нашему примеру.

По смыслу части 3 ст. 3.7 КоАП РФ, табачные изделия, запрещенные к обороту без соответствующей маркировки, не могут быть конфискованы: они подлежат уничтожению в установленном порядке [17].

Традиционный вопрос, который задают слушатели, повышающие квалификацию в стенах нашего Университета: если физическое лицо перемещает через таможенную границу табак или изделия из него с незначительным превышением установленных ограничений, изъятию подлежит весь табак или только его часть, в размере превышения таких лимитов?

Вопрос не случайный. При назначении конфискации, предусмотренной, например, за недекларирование товара для личного пользования, Конституционный Суд РФ [10; 11] предлагает руководствоваться той же логикой, что и при назначении административного штрафа: конфискации подлежит лишь часть товара, по стоимости превышающая стоимость товара, разрешенного к ввозу без таможенного обложения (см. примечание 1 к ст. 16.2 КоАП РФ). Остальной товар возвращается декларанту-нарушителю [см., например 16].

Логика подсказывает, что аналогичным образом следует поступать и при изъятии товара, очевидно предназначенного для личного пользования: разумно ожидать, что лишение имущества - неважно - в форме изъятия или конфискации, должно применяться с учетом особого правового режима перемещения товаров для личных нужд. Однако какие-либо пояснения высших органов правосудия по этому вопросу отсутствуют, в Проекте Кодекса этот вопрос также не решен.

Сложности возникают и при назначении административного наказания за нарушения таможенных правил при наличии т.н. идеальной совокупности. В науке проблемы применения статьи 4.4 КоАП РФ справедливо объясняются некоторой надуманностью ее конструкции [44, С. 46-48], и применительно к нашей теме исследования требуют более глубокого изучения.

Очевидно, после принятия нового КоАП РФ надлежит принять постановление Пленума Верховного Суда РФ по вопросам применения главы Особенной части КоАП РФ о нарушениях таможенных правил, в котором следует разъяснить также вопросы назначения административных наказаний за указанные виды деяний.

Кратко резюмируем изложенное. Одним из базовых принципов функционирования многосторонней торговой системы, в которую вплетается и интеграционное образование Евразийский экономический союз, является своевременная информированность участников ВЭД об установленных запретах и ограничениях в торговле товарами и ответственности за их несоблюдение. Ввиду того, что большая часть барьеров устанавливается на уровне Союза, целесообразно, на мой взгляд, выработать единые подходы:

- к определению понятия запретов и ограничений, их классификации, основанной на союзных нормах, а также единообразном толковании этих понятий во всех странах ЕАЭС.

- к формулированию статьей о нарушениях таможенных правил, в т.ч. нарушений запретов 
и ограничений в странах Союза (например, в Республике Беларусь отдельная статья, аналогичная ст. 16.3 КоАП РФ, в главе о нарушениях таможенных правил, отсутствует) [4, гл. 14];

- к установлению видов и размеров административных наказаний за идентичные нарушения таможенных правил, которые в значительной степени отличаются друг от друга в разных странах Союза.

При наличии единой таможенной границы и территории, сохраняющиеся различия превра- щаются в скрытый барьер в торговле.

В целях повышения информированности участников ВЭД на сайте Евразийской экономической комиссии возможно создать информационное окно, посредством которого на безвозмездной основе будет осуществляться консультирование участников ВЭД об установленных в законодательстве государств-членов Союза запретов и ограничений, а также об ответственности за их несоблюдение.

\section{Библиографический список}

1. Договор о Евразийском экономическом союзе от 29 мая 2014 г. (в ред. договоров от 10 октября 2014 г., 23 декабря 2014 г. и протоколов от 8 мая 2015 г., 15 марта 2018 г.) // СПС «КонсультантПлюс».

2. Договор о Таможенном кодексе Евразийского экономического союза (Подписан в г. Москве 11 апреля 2017 г.) (приложение № 1- Таможенный кодекс ЕАЭС) // Официальный сайт Евразийского экономического союза http://www.eaeunion.org/, 12.04.2017.

3. Ершов В.В. Правовое и индивидуальное регулирование общественных отношений. Монография. М.: РГУП, 2018. 628 c.

4. Кодекс Республики Беларусь об административных правонарушениях от 21 апреля 2003 г. № $194-3$ (с изм. и доп., включая от 18 декабря 2019 г.) // Национальный реестр правовых актов Республики Беларусь. 2003. № $87,2 / 980$.

5. одекс Республики Казахстан об административных правонарушениях от 05 июля 2014 г. № 235-V (с изм. и доп., включая от 04 мая 2020 г.) // Ведомости Парламента Республики Казахстан. 2014. № 18-II (2667-II). Ст. 92.

6. Кодекс Российской Федерации об административных правонарушениях от 30 декабря 2001 г. № 195 -Ф3 (с изм. и доп., включая от 20апреля 2020 г.) // СЗ РФ. 2002. № 1 (ч. 1). Ст. 1.

7. Международная конвенция по карантину и защите растений (Заключена в Риме 17 ноября 1997 г. Вступила в силу, в т.ч и для России, 2 октября 2005 года) // БМД. 2006. № 7. С. 56-84.

8. Определение Верховного Суда РФ от 07 марта 2017 г. № 307-АД16-16770 (Об отказе передачи кассационной жалобы Северо-Западной оперативной таможни на рассмотрение в Судебную коллегию по экономическим спорам Верховного Суда РФ, поскольку суд пришел к выводу об отсутствии в действиях общества состава административного правонарушения, квалифицируемого по ст. 16.3 КоАП РФ) // СПС КонсультантПлюс.

9. Определение Верховного Суда РФ от 17 апреля 2020 г. № 305-ЭС20-5316 по делу № А40-149577/2019 (Об отказе в передаче кассационной жалобы о пересмотре в кассационном порядке судебных актов по делу о признании незаконным и отмене постановления о привлечении к административной ответственности на основании статьи 16.3 КоАП РФ и материалов дела в Судебную коллегию по экономическим спорам ВС РФ отказано, так как суды пришли к правильному выводу об отсутствии в действиях истца состава правонарушения, поскольку на территорию Российской Федерации товар ввозился не с целью выпуска его в обращение на данной территории, а для помещения под режим таможенного транзита и дальнейшего ввоза на территорию Грузии) // СПС «КонсультантПлюс».

10. Определение Конституционного Суда РФ от 17 ноября 2011 г. № 1621-О-О «Об отказе в принятии к рассмотрению жалобы гражданина Макарьева Виталия Александровича на нарушение его конституционных прав частью 1 статьи 16.2 и частью 2 статьи 27.11 Кодекса Российской Федерации об административных правонарушениях» // СПС «КонсультантПлюс».

11. Определение Конституционного Суда РФ от 19 декабря 2017 г. № 3101-О «Об отказе в принятии к рассмотрению жалобы гражданки Онищенко Олеси Валерьевны на нарушение ее конституционных прав положениями ряда нормативных правовых актов» // СПС «КонсультантПлюс».

12. Официальный сайт ФТС России. Данные о результатах правоохранительной деятельности за I квартал 2020 г. URL: http:/customs.ru/activity/pravooxranitel-naya-deyatel-nost-/informacziya-upravleniya-tamozhennyxrassledovanij-i-doznaniya/document/235653 (дата обращения: 15.05.2020). 
13. Перечень категорий товаров, не относящихся к товарам для личного пользования (Приложение № 6 к Решению Совета ЕЭК от 20 декабря 2017 г. № 107 «Об отдельных вопросах, связанных с товарами для личного пользования» (с изм. и доп., включая от 28 мая 2019 г.) // СПС «КонсультантПлюс»).

14. Перечни товаров для личного пользования, в отношении которых подлежат соблюдению меры нетарифного регулирования; ветеринарно-санитарные меры; карантинные фитосанитарные меры; санитарные и радиационные требования.- URL: http://eеc.eaeunion.org/ru/act/tam_sotr/dep_tamoj_zak/Pages/fizlica_zapretyi-ogranicheniya.aspx (Дата обращения: 05.05.2020).

15. Постановление Арбитражного суда Московского округа от 16 января 2020 г. № Ф05-23632/2019 по делу № A40-149577/19-122-1225 (Об удовлетворении требований, содержащихся в кассационной жалобе общества, отмене судебных актов по заявлению общества к Северо-Осетинской таможне, а также постановления таможенного органа по делу о нарушении таможенных правил, квалифицированного по ст. 16.3 КоАП РФ) // СПС «КонсультантПлюс».

16. Постановление Верховного суда Республики Карелия от 19 июня 2019 г. № 4А-158/2019 // СПС «КонсультантПлюс».

17. Постановление Верховного Суда РФ от 20 сентября 2019 г. № 67-АД19-10 (Об изменении актов о привлечении к административной ответственности по делу о нарушении таможенных правил, предусмотренному ст. 16. 3 КоАП РФ, и о замене в них указании на конфискацию табачной продукции на ее уничтожение в установленном порядке) // СПС «КонсультантПлюс».

18. Постановление Заднепровского районного суда города Смоленска от 04 марта 2019 г. по делу 5-54/2019 (О признании российского перевозчика виновным в совершении административного правонарушения, предусмотренного ст. 16. 3 КоАП РФ, и назначении административного наказания) // СПС «КонсультантПлюс».

19. Постановление Пленума Верховного Суда РФ от 24 октября 2006 г. № 18 «О некоторых вопросах, возникающих у судов при применении Особенной части Кодекса Российской Федерации об административных правонарушениях» (в ред. от 25 июня 2019 г.) // БВС. 2006. № 12.

20. Постановление Правительства РФ от 19 сентября 2015 г. № 995 «Об утверждении Правил осуществления таможенными органами контроля за вывозом из Российской Федерации подкарантинной продукции» // СЗ РФ. 2015. № 39. Ст. 5410.

21. Постановление Правительства РФ от 20 февраля 2010 г. № 76 «Об акцизных марках для маркировки ввозимой в Российскую Федерацию табачной продукции» (с изм., включая 07 февраля 2019 г.) // СЗ РФ. 2010. № 9. Ст. 968.

22. Постановление Псковского городского суда псковской области от 29 октября 2018 г. по делу № 5-922/2018 (О прекращении производства по делу об АП, возбужденного в отношении общества по ст. 16.3 КоАП РФ в связи с отсутствием состава нарушения таможенных правил (фитосанитарный сертификат содержит информацию о номере вагона, куда погрузили зерновые, отличный от прибывшего вагона) // СПС «КонсультантПлюс».

23. Постановление Псковского областного суда от 11 января 2019 г. № 4a-8/2019 (О прекращении производства по делу о нарушении таможенных правил. Суд пришел к выводу о том, что в рассматриваемом случае неверное указание номера железнодорожного вагона в фитосанитарном сертификате, оформленном на вывозимый товар, не образует состава административного правонарушения, предусмотренного ст. 16. 3 КоАП РФ) // СПС «КонсультантПлюс».

24. Приказ Минсельхоза России от 27 октября 2016 г. № 478 «Об утверждении форм фитосанитарного сертификата, реэкспортного фитосанитарного сертификата, карантинного сертификата» // БНА. 2016. № 50.

25. Проект Кодекса РФ об административных правонарушениях (подготовлен Минюстом России, ID проекта 02/04/01-20/00099059) (не внесен в ГД ФС РФ, текст по состоянию на 30.01.2020) // СПС «КонсультантПлюс».

26. Протокол о мерах нетарифного регулирования в отношении третьих стран (Приложение № 7 к Договору о ЕАЭС) // «КонсультантПлюс».

27. Протокол о применении санитарных, ветеринарно-санитарных и карантинных фитосанитарных мер (Приложение № 12 К Договору о ЕАЭС) // «КонсультантПлюс».

28. Рамочная конвенция ВОЗ против табака (Заключена в Женеве 21 мая 2003 г. Россия присоединилась к Конвенции в 2008 г. См.: Федеральный закон от 24 апреля 2008 г. № 51-ФЗ) // СЗ РФ. 2008. № 17. Ст. 1758.

29. Рамочные стандарты безопасности и облегчения мировой торговли. Редакция 2018 г. (WCO Safe framework of standards).- URL: http:/www.wcoomd.org/-/media/wco/public/global/pdf/topics/facilitation/instrumentsand-tools/tools/safe-package/safe-framework-of-standards.pdf?la=en (дата обращения: 01.05.2020) 
30. Ревин В.Н. Формирование механизма нетарифного регулирования внешней торговли в России: дисс. ... канд. экон. наук. М., 1998. 178 с.

31. Решение Коллегии ЕЭК от 21 апреля 2015 г. № 30 «О мерах нетарифного регулирования» (ред. от 28 апреля 2020 г.) // СПС «КонсультантПлюс».

32. Решение Комиссии Таможенного союза от 07 апреля 2011 г. № 620 «О Едином перечне продукции, подлежащей обязательному подтверждению соответствия с выдачей сертификатов соответствия и деклараций о соответствии по установленной форме» (с изм. и доп., включая от 15 сентября 2017 г.) // СПС «КонсультантПлюс».

33. Решение Комиссии Таможенного союза от 18 июня 2010 г. № 318 «Об обеспечении карантина растений в Евразийском экономическом союзе» (с изм. и доп., включая от 17 марта 2017 г.) // СПС «КонсультантПлюс».

34. Решение Совета ЕЭК от 12 ноября 2014 г. № 107 «О Техническом регламенте Таможенного союза «Технический регламент на табачную продукцию» // СПС «КонсультантПлюс».

35. Таможенное право: учебник / отв. ред. О. Ю. Бакаева. 3-е изд., перераб. и доп. М.: Норма: ИНФРА-М, 2019. 592 с.

36. Трошкина Т.Н. Нетарифные меры в системе государственного регулирования международной торговли (на примере развитых стран) / под ред. В. С. Загашвили. М.: ЦППИ, 2010. 155 с.

37. Указ Президента РФ 22 октября 2018 г. № 592 «О применении специальных экономических мер в связи с недружественными действиями Украины в отношении граждан и юридических лиц российской Федерации» (с изм. от 24 июня 2019 г.) // СЗ РФ. 2018. № 44. Ст. 6706.

38. Указ Президента РФ от 06 августа 2014 г. № 560 «О применении отдельных специальных экономических мер в целях обеспечения безопасности Российской Федерации» (ред. от 24 июня 2019 г.) // СЗ РФ. 2014. № 32. Ст. 4470.

39. Федеральный закон от 30 декабря 2006 г. № 281-Ф3 «О специальных экономических мерах и принудительных мерах» (с изм. и доп., включая от 01 мая 2019 г.) // СЗ РФ. 2007. № 1 (ч.1). С. 44.

40. Федеральный закон от 03 августа 2018 г. № 289-Ф3 «О таможенном регулировании в Российской Федерации и о внесении изменений в отдельные законодательные акты Российской Федерации» // СЗ РФ. 2018. № 32 (ч.II). Ст. 5082.

41. Федеральный закон от 04 июня 2018 г. № 127-Ф3 «О мерах воздействия (противодействия) на недружественные действия Соединенных Штатов Америки и иных иностранных государств» // СЗ РФ. 2018. № 24. Ст. 3394.

42. Федеральный закон от 08 декабря 2003 г. № 164-Ф3 «Об основах государственного регулирования внешнеторговой деятельности» (с изм. и доп., включая от 01 мая 2019 г.) // СЗ РФ. 2003. № 50. Ст. 4850 (далее - Закон об основах государственного регулирования внешнеторговой деятельности).

43. Федеральный закон от 23 февраля 2013 г. № 15-Ф3 «Об охране здоровья граждан от воздействия окружающего табачного дыма и последствий потребления табака» (с изм. и доп., включая от 27 декабря 2019 г.) // С3 РФ. 2013. № 8. Ст. 721.

44. Якимов А. Ю. Усиление роли наказаний в административно-деликтном праве (произошедшие изменения и имеющиеся проблемы) // Административное право и процесс. 2019. № 10. С. 43-48. 